\title{
PENGEMBANGAN PERANGKAT PEMBELAJARAN BERBASIS PROBLEM BASED LEARNING DENGAN OUDOOR LEARNING PADA PEMBELAJARAN TEMATIK SUBTEMA KEUNIKAN DAERAH TEMPAT TINGGALKU PADA SISWA SEKOLAH DASAR
}

\author{
${ }^{1}$ Rachmad Himawan Suryanegara, ${ }^{2}$ Nasution, ${ }^{3}$ Waspodo Tjipto \\ ${ }^{1}$ Mahasiswa Program Pascasarjana, Prodi Pendidikan Dasar, Universitas Negeri Surabaya, \\ ${ }^{2 \& 3}$ Dosen Pascasarjana, Prodi Pendidikan Dasar, Universitas Negeri Surabaya \\ e-mail: himawan.padamu14@gmail.com
}

Received : November 2017

Reviewed: Desember 2017

Accepted : Januari 2018

Published : Januari 2018

\section{ABSTRACT}

Research is an approach of research and development aimed at (1) mendeskrpsikan device eligibility based learning Problem Based Learning with outdoor learning theme unique to the area where I live that has been developed, (2) describe the effectiveness of the device's eligibility based learning Problem Based Learning with outdoor learning unique to the area where I live which has been developed. This research was conducted in SDN Medokan Ayu I / 270 Surabaya, with research subjects are students of class IV A SDN Medokan Ayu I / 270 Surabaya as grade control and IV B SDN Medokan Ayu I / 270 Surabaya as an experimental class of the school year 2015/2016. This type of research is research development to shape the research design 4-D. The data was obtained as follows: feasibility devices based learning Problem Based Learning with oudoor learning that has been developed developed declared eligible. This is indicated by the assessment of experts validator device that shows the percentage of the assessment results of $87.5 \%$. As for testing the hypothesis analyzed by t-test showed that the learning outcomes of students in the experimental class is higher than the control class. This is indicated by the value of the $t(2081)>t$ table $(1,668)$ with a mean value of the experimental class of $97 \%$ higher than the learning outcomes of students in grade control, namely $82 \%$. Thus, the use of the learning model Problem Based Learning with outdoor learning effect on student learning outcomes. Based on the analysis, it can be concluded that devices based learning Problem Based Learning with oudoor learning theme unique to the area where I live effectively improve student learning outcomes fourth grade of primary school

Keyword: Development, learning tools, model Problem Based Learning, Outdoor Learning.

\section{ABSTRAK}

Penelitian merupakan pendekatan dari penelitian pengembangan bertujuan untuk (1) mendeskrpsikan kelayakan perangkat pembelajaran berbasis Problem Based Learning dengan oudoor learning tema keunikan daerah tempat tinggalku yang telah dikembangkan, (2) mendeskripsikan efektivitas kelayakan perangkat pembelajaran berbasis Problem Based Learning dengan oudoor learning keunikan daerah tempat tinggalku yang telah dikembangkan. Penelitian ini dilakukan di SDN Medokan Ayu I/270 Surabaya, dengan subjek penelitian adalah siswa kelas IV A SDN Medokan Ayu I/270 Surabaya sebagai kelas kontrol dan IV B SDN Medokan Ayu I/270 Surabaya sebagai kelas eksperimen tahun pelajaran 2015/2016. Jenis penelitian yang dilakukan adalah penelitian pengembangan dengan bentuk desain penelitian 4-D. Data hasil penelitian yang diperoleh sebagai berikut: kelayakan perangkat pembelajaran berbasis Problem Based Learning dengan outdoor learning yang telah dikembangkan yang dikembangkan dinyatakan layak. Hal ini ditunjukkan dengan penilaian dari validator ahli perangkat yang menujukkan 
presentase hasil penilaian sebesar $87,5 \%$. Sedangkan untuk pengujian hipotesis yang dianalisa dengan uji t menunjukkan bahwa hasil belajar siswa pada kelas eksperimen lebih tinggi dibandingkan pada kelas kontrol. Hal ini ditunjukkan dengan nilait hitung $(2.081)>\mathrm{t}_{\text {tabel }}$ (1.668) dengan nilai mean pada kelas eksperimen sebesar $97 \%$ lebih tinggi dibandingkan dengan hasil belajar siswa pada kelas control yaitu 82\%. Jadi, penggunaan model pembelajaran Problem Based Learning dengan outdoor learning berpengaruh terhadap hasil belajar siswa.Berdasarkan hasil analisis data, dapat disimpulkan bahwa perangkat pembelajaran berbasis Problem Based Learning dengan oudoor learning tema keunikan daerah tempat tinggalku efektif meningkatkan hasil belajar siswa kelas IV sekolah dasar.

Kata Kunci: Pengembangan, Perangkat pembelajaran, model Problem Based Learning, Outdoor Learning

\section{PENDAHULUAN}

Pendidikan adalah salah satu kualitas yang ditentukan suatu bangsa. Pendidikan memiliki peranan yang sangat penting untuk menciptakan bangsa yang cerdas, damai, terbuka dan demokratis. Menurut (Erik De Graff 2003 : 657) pembaharuan di bidang pendidikan harus selalu dilakukan untuk meningkatkan kualitas pendidikan nasional. Harkat dan martabat rakyat Indonesia dapat meningkat jika kualitas pendidikan di Indonesia meningkat atau berubah lebih baik.

Menurut Sukmadinata (dalam Suyono, 2011:129) bahwa dalam belajar dapat terjadi hambatan-hambatan. Hambatan dapat terjadi karena belum adanya penyesuain individu dengan tugasnya, kurang motivasi, kelelahan, atau kejenuhan dalam belajar. Sehingga pada proses pembelajaran terasa sangat membosankan, apalagi kecenderungan siswa yang hanya berdiam diri atau tidak lagi memperhatikan pembelajaran yang disampaikan oleh guru. Dilihat dari fenomena yang terjadi pada siswa-siswa saat ini, mereka menganggap bahwa aktivitas yang menyenangkan justru berada di luar jam pelajaran (Hamid, 2012:12)

Menurut (Christina De Simone, 2014:12) lingkungan adalah keadaan sekitar yang mempengaruhi perkembangan dan tingkah laku makhluk hidup dan segala sesuatu yang ada disekitar manusia yang mempengaruhi perkembangan kehidupan manusia baik langsung maupun tidak langsung. Kehidupan manusia sangat tergantung pada tersedianya sumber daya alam yang memadai dalam lingkungan hidup. Sesungguhnya sangat disadari bahwa lingkungan hidup berperan penting dalam perkembangan kebudayaan dan pendidikan manusia

Pendidikan adalah menyiapkan peserta didik agar mampu beradaptasi dan berinteraksi dalam kehidupan nyata (Orla C. Kelly 2007: 347). Pendidikan adalah suatu proses dalam rangka mempengaruhi siswa agar dapat menyesuaikan diri sebaik mungkin terhadap lingkungannya, dan dengan demikian akan menimbulkan perubahan dalam dirinya yang memungkinkannya dapat berfungsi dalam kehidupan masyarakat. (Sigit, 2013:12). Kepedulian terhadap lingkungan dapat diajarkan sejak dini kepada siswa melalui pembalajaran yang dilakukan setiap hari.

Sejauh ini proses pembelajaran di sekolah masih didominasi oleh sebuah paradigma yang menyatakan bahwa sebuah pengetahuan merupakan perangkat faktafakta yang harus dihafal. Murid sebatas pendengar pasif dengan sikap diam, mendengarkan, merekam mencatat apa yang disampaikan oleh guru. Siswa menganggap bahwa mata pelajaran bahwa mata pelajaran IPS saat ini dengan model pembelajaran guru yang konvensional didalam kelas sangat membosankan serta mendapatkan rasa kejenuhan tersendiri.

Selain itu, siswa kesulitan dalam menyerap dan mencerna apa yanh disampaikan oleh guru karena siswa harus menerima apapun dan bagaimanapun dari guru itu. Hal ini sesuai dengan yang disampaikan Muwarni (2006:59) bahwa: murid secara dogmatic menerima 'kebenaran' dari guru, tanpa ada mekanisme untuk memahami 'makna' ideologi dari setiap konsepsi atas kehidupan masyarakat. Disamping itu juga pembelajaran IPS yang berpusat pada guru menjadikan siswa hanya obyek pembelajaran saja apalagi muncul persepsi bahwa pelajaran IPS adalah pelajaran yang bersifat hafalan semata dan kurang bergairah dalam mempelajarinya. Maka dari itu, dibutuhkan inovasi pembelajaran agar para siswa menajdi bersemangat, mempunyai motivasi untuk belajar, antusias menyambiut pelajaran di sekolah, aktif dalam setiap kegiatan, dan memperoleh hasil belajar yang diharapkan.

Pembelajaran IPS di kelas diubah dari suatu yang membosankan menjadi sesuatu yang menyenangkan, dari 
sesuatu yang membosankan menjadi sesuatu yang membahagiakan, atau dari sesuatu yang dibenci menjadi sesuatu yang dirindukan oleh siswa. pada penelitian ini digunakan model Problem Based Learning menggunakan Oudoor learning.

Model Problem Based Learning menggunakan oudoor learning menekankan pada proses belajar mandiri dimana kegiatan pembelajarannya secara langsung dapat dialami oleh siswa, sehingga siswa diharapkan dapat membangun makna atau kesan pengetahuan dalam ingatan. Sebagaimana pernyataan (DePorter 2003:6). "Bawalah dunia mereka ke dunia kita dan antarkan dunia kita ke dunia mereka" dan "semakin jauh anda memasuki dunia siswa maka semakin jauh pengaruh yang dapat anda berikan kepada mereka".

Salah satu rencana model pembelajaran Problem Based Learning dengan Oudoor learning juga menggunakan pembelajaran di luar kelas, hal ini dimaksudkan agar siswa bergairah dalam melaksanakan pembelajaran dan mengubah persepsi siswa tentang pembeljaran IPS yang membosankan serta dilakukan di dalam kelas.

Berdasarakan paparan di atas, maka peneliti merasa perlu dikembangkan perangkat pembelajaran yang dapat merangsang siswa untuk aktif, menumbuhkan minat dan antusias dalam mencari pengetahuan, salah satu pengembangan perangkat tersebut adalah dengan "Pengembangan Perangkat Pembelajaran berbasis Problem Based Learning dengan Oudoor learning pada Pembelajaran Tematik Subtema Keunikan Daerah Tempat Tinggalku pada Siswa Sekolah Dasar".

Pada penelitian ini rumusan masalah yang akan dibahas adalah: 1. Bagaimanakah kelayakan perangkat pembelajaran berbasis Problem Based Learning dengan oudoor learning pada pembelajaran tematik subtema keunikan daerah tempat tinggalku pada siswa sekolah dasar? 2. Bagaimanakah keefektifan perangkat pembelajaran berbasis Problem Based Learning dengan oudoor learning pada pembelajaran tematik subtema keunikan daerah tempat tinggalku pada siswa sekolah dasar? Mengacu pada rumusan masalah di atas, maka tujuan penelitian ini adalah sebagai berikut: 1 . Mengetahaui kelayakan perangkat pembelajaran berbasis Problem Based Learning dengan oudoor learning pada pembelajaran tematik subtema keunikan daerah tempat tinggalku pada siswa sekolah dasar. 2. Mengetahui keefektifan perangkat pembelajaran berbasis Problem Based Learning dengan oudoor learning pada pembelajaran tematik subtema keunikan daerah tempat tinggalku pada siswa sekolah dasar.
Hasil penelitian ini diharapkan dapat memberikan manfaat bagi banyak pihak: manfaat Teoriti: Sebagai masukan kajian di lingkungan akademik Universitas Negeri Surabaya khususnya Program Pascasarjana Program Studi Pendidikan Dasar tentang pengembangan perangkat pembelajaran berbasis model problem based learning dengan outdoor learning pada kelas IV sekolah dasar, manfaat praktis: penggunaan ini dimaksudkan dapat bermanfaat bagi guru SD dalam menyelenggarakan aktivitas pembelajaran IPS siswa kelas IV dengan menggunakan model problem based learning dengan outdoor learning pada kelas IV sekolah dasar.

\section{KAJIAN PUSTAKA}

Menurut Taufiq (2009:7), model pembelajaran dimaksudkan sebagai pola interaksi siswa dengan guru di dalam kelas yang menyangkut strategi, pendekatan, metode, dan teknik pembelajaran yang diterapkan dalam pelaksanaan kegiatan belajar mengajar di dalam kelas.

Menurut Trianto (2007:67), model PBL merupakan suatu model pembelajaran yang didasarkan pada banyaknya permasalahan yang membutuhkan penyelidikan autentik yakni penyelidikan yang membutuhkan penyelesaian nyata dari permaslahan yang nyata.

Menurut Arend (dalam Trianto, 2007:68), PBL merupakan suatu pendekatan pembelajaran dimana siswa mengerjakan permasalahan yang Autentik dengan maksud untuk menyusun pengetahuan mereka sendiri, lebih tinggi, mengembangkan kemandirian dan percaya diri.

Model PBL adalah interaksi antar stimulus dengan respon, hubungan antara dua arah belajar dengan lingkungan. Lingkungan memberi masukan kepada siswa berupa bantuan dan masalah, sedangakn system saraf otak berfungsi menafsirkan bantuan itu secara efektif sehingga masalah yang dihadapi dapat diselidiki, dinilai, dianalisis serta dicari pemecahannya. PBL mempunyai beberapa tujuan sebagai berikut: (a) membantunu siswa mengembangakan keterampilan berfikir dan keterampilan pemecahan masalah, (b) belajar peranan orang dewasa yang autentik (c) menjadi pembelajar yang mandiri. Arends (dalam suprayitno, 2011:62) PBL mempunyai karakteristik sebagai berikut: (a) pengajuan pertanyaan dan masalah, (b) berfokus pada keterkaitan antar disiplin, (c) penyelidikan autentik, (d) menghasilkan produk, dan (e) kolaborasi.

Teori yang melandasi problem based learning adalah sebagai berikut:

a. Teori Konstruktivisme (Contructivism)

Teori konstruktivisme dibagi menjadi dua, yaitu teori konstruktivisme kognitif dan teori konstruktivisme sosial. Dalam teori konstruktivistik 
kognitif, belajar adalah proses perubahan dalam struktur kognitif seseorang sebagai hasil konstruksi pengetahuan yang bersifat individual dan internal. Perubahan tersebut didorong oleh rasa ingin tahu. Selain itu dalam usaha membangun pengetahuannya saat berinteraksi dengan lingkungan, individu melakukan pengujian serta memodifikasi skema pengetahuannya yang telah ada. Interaksi yang terjadi bertindak sebagai katalis untuk membangun konflik kognitif dalam individu. Ketika konflik itu muncul, individu akan terdorong untuk melakukan prosesproses penyesuaian struktur kognitifnya dalam usaha membangun pemahaman terkait fakta/fenomena tersebut (Hitipiew, 2009: 93).

b. Teori Piaget

Menurut Piaget dalam Julianto pengetahuan datang dari tindakan. Jadi perkembangan kognitif sebagian besar bergantung kepada seberapa jauh anak aktif memanipulasi dan aktif berinteraksi dengan lingkungannya. Implikasi dari teori Piaget dalam pembelajaran adalah sebagai berikut:

1) Memfokuskan pada proses berfikir atau proses mental anak tidak sekedar pada produknya. Disamping kebenaran jawaban siswa, guru harus memahami proses yang digunakan anak sehingga sampai pada jawaban tersebut.

2) Pengenalan dan pengakuan atas peranan anakanak yang penting sekali dalam inisiatif diri dan keterlibatan aktif dalam kegiatan pembelajaran.

3) Tidak menekankan pada praktek-praktrek yang diarahkan untuk menjadikan anak-anak seperti orang dewasa dalam pemikirannya.

4) Penerimaan terhadap perbedaan individu dalam kemajuan perkembangan, teori piaget mengasumsikan bahwa seluruh anak berkembang melalui urutan perkembangan yang sama namun mereka memperolehnya dengan kecepatanyang berbeda.

c. Teori Vygotsky

Lev Vygotsky (1896-1934) dalam Nur azizah berpendapat bahwa perkembangan kognitif dan bahasa anak-anak tidak berkembang dalam suatu situasi sosial yang hampa. Vygotsky tidak setuju dengan pandangan Piaget bahwa anak menjelajahi dunianya sendiri dan membentuk gambaran realitas batinnya sendiri. Vygotsky menekankan bagaimana proses-proses perkembangan mental seperti ingatan, perhatian, dan penalaran melibatkan pembelajaran menggunakan temuan-temuan masyarakat seperti bahasa, sistem matematika, dan alat-alat ingatan. d. Teori Ausubel Tentang Belajar Bermakna

Menurut Ausubel dalam Dahar, belajar dapat diklasifikasikan ke dalam dua dimensi yaitu berhubungan dengan cara informasi atau materi pelajaran yang disajikan pada pelajar melalui penerimaan (reception learning) atau penemuan (discovery learning) dan menyangkut cara bagaimana pelajar dapat mengaitkan informasi itu pada struktur kognitif yang telah ada, yaitu belajar bermakna (meaningful learning) atau hafalan (rote meaningful). Pembelajaran bermakna merupakan suatu proses yang mengaitkan informasi baru pada konsep-konsep relevan yang terdapat dalam struktur kognitif seseorang.

e. Teori Bruner

Menurut Bruner, agar proses mempelajari sesuatu pengetahuan atau kemampuan berlangsung secara optimal, dalam arti pengetahuan taua kemampuan dapat diinternalisasi dalam struktur kognitif orang yang bersangkutan. Kemampuan tersebut dibagi dalam 3 tahap yaitu, tahap enaktif, tahap ikonik, dan tahap simbolik.

Menurut Barlet (dalam Husamah. 2013:20) adalah pembelajaran pendidikan luar ruang adalah suatu pembelajaran yang dilakukan di luar ruang atau luar kelas, berbeda halya dengan Hariyati (dalam Husamah. 2013:20) yang menguraikan nilai postif outdoor learning adalah proses pembelajaran yang dapat membangun makna (input), kemudian prosesnya melalui struktur kognitif sehingga berkesan lama dalam ingatan atau memori (terjadi rekonstruksi).

Pembelajaran outdoor merupakan salah satu jalan bagaimana kita meningkatkan kapasitas belajar anak. Anak dapat belajar secara lebih mendalam melalui objek-objek yang diahadapi dari pada jika belajar didalam kelas yang memiliki banayak keterbatasan, hal ini senada dengan pendapat Freire (2002:80) yang mengatakan bahwa every place is a school, everyone is a teacher (setiap orang adalah guru, guru bisa siapa saja, dimana saja, serta hadir kapan saja, tanpa batas ruang, waktu, kondisi apapun). Hal ini menegaskan siapa saja dapat menjadi guru dan pembelajaran tidak harus berlangsung didalam kelas, sebab setiap tempat dapat menjadi tempat untuk belajar.

\section{METODE PENELITIAN}

Rancangan penelitian uji coba di lapangan pengembangan media problem bassed learning dengan outdoor learning yang menggunakan rancangan 
randomized control-group pretest-posttest design yang dikembangkan oleh Suryabrata (2011:203).

Pada desain ini diberikan tes awal dan tes akhir pada kelas eksperimen maupun kelas control. Kelompok eksperimen adalah kelompok yang diberikan perlakuan dengan menggunakan media pembelajaran pada proses belajar mengajarnya, sedangkan pada kelas control tidak menggunakan model pembelajaran. dibawah ini

Tabel 1

\begin{tabular}{ccccc}
\hline & Kelompok & Tes Awal & Perlakuan & Tes Akhir \\
R & Eksperimen & T1 & X & T2 \\
kontrol & T1 & - & T2 \\
\hline \multicolumn{3}{c}{ (Sumber:Suryabrata 2011:205) }
\end{tabular}

Keterangan:

$\mathrm{R}=$ Kelompok eksperimen dan kelompok control dipilih secara random.

$\mathrm{T}_{1}=\mathrm{Uji}$ awal (pretest), untuk mengetahui penguasaan awal siswa terhadap pengetahuan tentang materi sebelum diberikan perlakuan

$\mathrm{T}_{2}=\mathrm{Uji}$ akhir (posttest), untuk mengetahui penguasaan siswa terhada pengetahuan tentang materi.

$\mathrm{X}=$ Perlakuan yaitu pelaksanaan pembelajaran dengan menggunakan

Prosedur dalan rancangan desain eksperimen ini dimulai dengan memilih subjek secara acak dari populasi. kemudian dikelompokkan menjadi kelompok eksperimen dan control. Kedua kelompok diberikan pretest untuk mengukur variable tergantung dari kedua kelompok tersebut lalu dihitung mean dari masing-masing kelompok.

\section{HASIL DAN PEMBAHASAN}

Pada bab ini akan dibahas tentang temuan-temuan atau kajian-kajian empirik terkait dengan teori dan penelitin yang relevan sebelumnya tentang pengembangan perangkaat pembelajaran berbasis model problem based learning dengan outdoor learning pada sub tema keunikan daerah tempat tinggalku untuk meningkatkan hasil belajar kelas IV SDN Medokan Ayu I/270.

a. Analisis Validasi Perangkat Pembelajaran

Sebelum menerapkan perangkat pembelajaran yang telah dikembangkan, peneliti melakukan validasi perangkat pembelajaran. Validator perangkat pembelajaran adalah Drs. Suprayitno, M.Pd sebagai validator I dan Putri Rachmadyanti, M.Pd sebagai validator II. Perangkat pembelajaran yang divalidasi antara lain Rencana Pelaksanaan Pembelajaran (RPP), Lembar Kerja Siswa (LKS), Tes Hasil Belajar (THB) dan Materi Ajar. Skor yang diperoleh pada masing masing aspek menunjukkan validitas dari suatu perangkat pembelajaran yang dikembangkan. Sehingga dapat dinyatakan bahwa valid atau tidaknya perangkat pembelajaran bergantung pada skor yang diperoleh dari setiap aspek.

1. Rencana Pelaksanaan Pembelajaran (RPP)

Rencana Pelaksanaan Pembelajaran yang dikembangkan peneliti dengan subtema keunikan daerah tempat tinggalku. Rencana Pelaksanaan Pembelajaran (RPP) yang dikembangkan berbasis problem based learning (PBL) dengan outdoor learning. Rencana Pelaksanaan Pembelajaran (RPP) yang telah dikembangkan peneliti kemudian ditelaah dan divalidasi oleh dua orang pakar dalam bidang pendidikan.

Berdasarkan hasil validasi dapat diketahui bahwa Rencana Pelaksanaan Pembelajaran (RPP) menggunakan model problem based learning (PBL) dengan outdoor learning mendapat rata-rata 3,5. Berdasarkan koefisien validitas perangkat pembelajaran, maka Rencana Pelaksanaan Pembelajaran (RPP) dengan model problem based learning (PBL) dengan outdoor learning tergolong valid dan layak untuk digunakan.

Berdasarkan penjelasan di atas maka Pelaksanaan Pembelajaran (RPP) yang telah dikembangkan dan direvisi dapat digunakan dalam pembelajaran.

2. Tes Hasil Belajar (THB)

Dari hasil validasi Tes Hasil Belajar (THB) menunjukan validator I dengan skor total 40 dengan presentase $100 \%$. Dengan demikian THB dikatakan sangat baik karena bernilai $\geq 81 \%$ menurut interpretasi dapat digunakan dengan sedikit revisi.

Setelah mendapatkan saran dan catatan dari validator, peneliti memperbaiki Tes Hasil Belajar (THB) agar menjadi lebih baik dan layak untuk digunakan.Dari hasil jumlah rata-rata presentase keseluruhan validasi diperoleh $100 \%$ dan dikategrikan baik dan layak digunakan.

3. Materi Ajar

Dari hasil validasi materi ajar pada table 4.3 dapat ditunjukkan bahwa validitas materi ajar sebagai berikut jumlah total 45 . Rata-rata 3 dan persentase $75 \%$. Hal ini menunjukkan bahwa validitas materi ajar pada kategori baik.

Berdasarkan penjelasan di atas maka buku siswa yang telah dikembangkan dan direvisi dapat digunakan untuk penelitian.

4. Lembar Kerja Siswa (LKS) 
Lembar Kerja Siswa (LKS) yang dikembangkan peneliti berbasis model problem based learning (PBL) dengan outdoor learning ini merupakan panduan siswa dalam kegiatan penyelidikan di dalam kegiatan pembelajaran yang harapannya dapat meningkatkan hasil belajar..

b. Analisis Pelaksanaan Pembelajaran

Kegiatan pembelajaran dalam penelitian ini diamati oleh pengamat atau (observer). Berdasarkan aspek yang diamati secara keseluruhan meliputi kegiatan pendahuluan, inti, penutup, pengelolahan waktu, dan suasana kelas. Pengamatan pada kegiatan pendahuluan merupakan fase pertama hal ini guru secara aktif memotivasi siswa untuk fokus dalam kegiatan pembelajaran, serta melakukan apersepsi mengkorelasikan pada pembelajaran sekarang dengan pembelajaran sebelumnya, serta menyampaikan tujuan secara eplisit tentang pencapaian dalam kegiatan pembelajaran. Pada pelaksanaan inti merupakan kegiatan untuk mencapai kompetensi dasar secara partisipatif, inspiratif, kreatif, menyenangkan, menantang sehingga anak ikut serta dalam kegiatan pembelajaran dengan antusian dan semangat. Pada kegiatan inti siswa melakukan kegiatan berdasarkan model pembelajaran problem based learning (PBL) dengan outdoor learning. Kegiatan penutup, guru bersama peserta didik membuat rangkuman atau simpulan, memberikan umpan balik terhadap proses pembelajaran dengan pemberian tugas kepada siswa, serta menyampaikan kegiatan berikutnya.

c. Analisis Tes Hasil Belajar dengan Model Problem Based Learning(PBL)

Hasil belajar siswa setelah menggunakan model problem based learning dengan outdoor learning dapat dilihat pada masing-masing kompetensi, kopetensi yang dimaksud yaitu sikap, sepiritual, sosial, pengetahuan, dan keterampilan. Pertama, pada kompetensi sikap sepiritual, peningkatan hasil belajar terlihat signifikan karena pada masing-masing pertemuan, sudah menunjukkan sikap sepirtual yang baik, sikap sepiritual yang diukur yaitu berdo'a sebelum dan sesudah aktivitas serta memberi dan menjawab salam.

Kedua, pada kompetensi sikap sosial, peningkatan hasil belajar tercapai pada sikap disiplin, tanggung jawab dan percaya diri. Pada sikap sosial jujur, kompetensi siswa sudah menunjukkan kategori sangat baik.

Ketiga, pada kompetensi pengetahuan, terlihat dari hasil pengerjaan soal pre-test dan soal post-test.
Pada kelas eksperimen yang dilakukan oleh kelas IV A, peningkatan tercapai lebih tinggi yaitu dari 62,9 pada hasil pre-test menjadi 80,2 pada hasil post-test.

Pada analisis sebelumnya diperoleh nilai $t_{\text {hitung }}$ hasil belajar siswa sebesar 2.081 (df. 65). Dari hasil analisis dengan uji Independent Sample T-test tersebut diperoleh nilai $t_{\text {hitung }}(2.081)>t_{\text {tabel }}$ (1.668) pada df. 65 dan s nilai signifikansi tersebut lebih kecil dari nilai $\alpha$ $(0,041<0,05)$ maka hipotesis nihil (Ho) yang diajukan ditolak dan hipotesis alternatif (Ha) diterima. Jadi dapat disimpulkan bahwa "ada pengaruh dari pengembangan perangkat pembelajaran menggunakan problem bassed learning dengan outdor learning pada sekolah dasar". Berdasarkan hasil diatas, maka telah terbukti bahwa rata-rata hasil belajar siswa pada kelas eksperimen lebih baik secara signifikan. Hal ini menunjukkan bahwa hasil belajar siswa yang mengikuti pembelajaran menggunakan model problem bassed learning dengan outdor learninglebih baik daripada hasil belajar siswa yang mengikuti pembelajaran tanpa menggunakan model problem bassed learning dengan outdor learning.

Hasil belajar diperoleh dari tes hasil belajar siswa, yaitu tes awal (pretes) untuk mengetahui kemampuan awal siswa sebelum diberikan perlakuan dan tes akhir (postest) setelah diberikan perlakuan, untuk mengetahui hasil belajar dengan menggunakan model problem based learning (PBL) dengan outdoor learning. Kriteria ketuntasan minimal SDN Medokan Ayu I/270 Surabaya $\geq 75$, jadi siswa dianggap tuntas dan meningkat hasil belajarnya jika mencapai 75 .

Keempat, pada kompetensi keterampilan, terjadi peningkatan hasil belajar utamanya keterampilan beragumentasi. Argumentasi yang dilakukan secara individu memiliki perbedaan dengan argumentasi yang dilakukan secara kelompok. Pada setiap pertemuan, siswa senantiasa didorong untuk menyampaikan argumentasinya, baik ketika memberikan argumenasi tentang memberi tanggapan, mengerjakan LKS, maupun waktu presentasi. Hal ini sesuai teori yang telah disampaikan oleh Vygotsky, Vygotsky lebih menekankan pada aspek sosial pembelajaran. Vygotsky percaya bahwa interaksi sosial yang terjadi antara siswa dengan siswa lain akan mampu terbentuknya ide baru dan memperkaya perkembangan intelektual siswa. Kondisi ini terjadi pada saat pengerjaan LKS.

Hal ini sesuai dengan pendapat Ausubel, bahwa belajar dikatakan bermakna jika informasi yang akan dipelajari peserta didik disusun sesuai dengan struktur kognitif yang dimiliki peserta didik, sehingga 
peserta didik dapat mengaitkan informasi barunya dengan struktur kognitif yang dimilikinya. Hal ini juga sejalan dengan pendapat dari Jhon Dewey yang menyatakan bahwa guru harus mendorong siswa terlibat dalam proyek atau tugas berorientasi masalah dan membantu mereka menyelidiki masalah-masalah intelektual dan sosial. Dasar ini sebagai pengembangan problem based learning (PBL) dengan outdoor learning dan terbukti dari hasil penelitian siswa mampu menyelesaiakn masalah begitu juga dengan pembelajaran menggunakan problem based learning(PBL) dengan outdoor learning hasil belajar siswa meningkat terutama pada tingkat kognitif level C4 (Menganalisis), hal ini membuktikan bahwa problem based learning (PBL) dengan outdoor learning sangat efektif digunakan dalam pembelajaran.

Berdasarkan tabel validasi tes hasil belajar dapat diketahui butir soal yang sudah dinyatakan valid oleh dosen ahli, selanjutnya diuji tingkat reliabilitasnya. Reliabilitas menunjukkann tingkat keandalan instrument dalam menjalankan fungsinya sebagai alat ukur. Tarafrelibilitas suatu tes dinyatakan dalam suatu angka koefisien relibilitas.

Untuk menguji kesamaan varian dapat dilihat pada angka $\mathrm{F}$ yang menggunakan kedua varian sama adalah 2,613 dengan signifikansi 0,111. Karena angka signifikasi > 0,05 maka dapat disimpulkan bahwa varians sampel adalah homogen. Kedua kelas mengasumsikan sama pada hasil t-test dengan probabilitas (sig) sebesar 0,210. Oleh karena itu angka probabilitas >0,05, maka dapat diartikan tidak ada perbedaan secara signifikan.

Berdasarkan tabel hasil belajar siswa (posttest) dapat diketahui kesamaan varian dapat dilihat pada angka $\mathrm{F}$ yang mengasumsikan kedua varian sama adalah 0,750 dengan probabilitas (sig) sebesar 0,390. Oleh karena itu angka probabilitas > 0,05, berarti tidak ada perbedaan antara kelas eksperimen dan kelas kontrol pada tes hasil belajar.

Untuk mengetahui perbandingan post-tes hasil belajar kelas eksperimen dan kelas control dapat dilihat pada angka t-tess yang mengasumsikan kedua populasi sama adalah -4,917dengan probabilitas (sig) sebesar 0,000 . Oleh karena itu angka probabilitas $<0,05$, dapat diartikan adanya perbedaan antara nilai yang diperoleh kelas eksperimen dan kelas kontrol. Sehingga dapat disimpulkan, bahwa terdapat perbedaan hasil belajar antara kelompok eksperimen dan kelompok kontrol.

Melalui uji-t test correlated/paired kelas eksperimen dan kelas kontrol pada tahap pre-test kedua kelas mendapat nilai yang sama. Adapun kelas eksperiment diberikan perlakuan dengan model problem based learning (PBL) sehingga dapat disimpulkan, ada pengaruh pengembangan perangkat pembelajaran dengan model problem based learning (PBL) terdapat peningkatan tes hasil belajar siswa kelas VI SDN Medokan Ayu I/270 Surabaya.

\section{PENUTUP}

\section{A. Kesimpulan}

Berdasarkan hasil penelitian, maka dapat disimpulkan bahwa perangkat pembelajaran berbasis model problem based learning dengan outdoor learning yang dikembangkan berdasarkan model 4-D sebegai berikut:

1. Dari hasil uji validitas pengembangan tersebut, perangkat pembelajaran berbasis model problem based learning dengan outdoor learning dilakukan oleh dua orang validator ahli yakni pertama ahli pendidikan dan yang kedua ahli substansi dinyatakan valid atau layak sebagai bahan pembelajaran pada siswa kelas IV sekolah dasar. Dengan demikian perangkat pembelajaran model problem based learning dengan outdoor learning subtema keunikan daerah tempat tinggalku dapat digunakan sebagai bahan ajar untuk kelas IV sekolah dasar.

2. Uji keefektifan menunjukkan bahwa hasil belajar siswa yang mengikuti pembelajaran berbasis model problem based learning dengan outdoor learning lebih tinggi daripada hasil belajar siswa yang tidak mengikuti pembelajaran model PBL. Dengan demikian, perangkat pembelajaran model problem based learning dengan outdoor learning subtema keunikan daerah tempat tinggalku efektif dalam meningkatkan hasil belajar siswa kelas IV Sekolah Dasar.

\section{B. Saran}

Berdasarkan kesimpulan seperti yang dipaparkan di atas disarankan hal-hal sebagai berikut:

1. Selayaknya guru mengimplementasikan model pembelajaran di luar kelas agar pembelajaran lebih menarik dan bermakna serta siswa tidak mudah bosan saat pembelajaran dimulai karena peserta didik taraf perkembangannya masih berfikir konkret.

2. Sebaiknya guru memilih metode pembelajaran yang tepat sehingga proses pembelajaran di kelas menjadi menarik, actual dan fungsional bagi siswa, serta membuat prestasi belajar siswa 
meningkat sehingga bukan hannya berorientasi pada teacher centered (berpusat pada guru)

3. Pada pembelajaran di luar kelas sebaiknya guru lebih meningkatkan dalam penggunaan model PBL agar kegiatan belajar siswa lebih menarik sehingga siswa dapat dengan tenang mengerjakan soal dan menjawab pertanyaan dengan benar. Apabila siswa tenang dalam belajar di sekolah maka hasil belajar siswa akan meningkat.

\section{DAFTAR PUSTAKA}

Amir, Taufik. (2009). Inovasi Pendidikan Melalui Problem Bassed Learning. Jakarta Kencana Prenada Media Grup.

Arikunto, Suharsimi (2010). Prosedur penelitian (Suatu Pendekatan Praktik). Jakarta: PT Rineka Cipta.

Arzu Ari. (2013) The Opinions of Primary Mathemtics Student-Teachers on Problem Bassed Learning Method Kocaeli University: Education Faculty Primary Department.

Bandono. (2009, Desember 2015). Panduan Pengembangan Bahan Ajar. Dari http://www.Wikipedia.org/

Barbara. (2009). Implememnting Problem Bassed Learning in an Undergraduate Psychology Course: A Journal of Scholary Teaching.

Borg, W. R \& Gall, M. D. Gall. (1989). Educational Research: An Introduktion, Fiifth Edition. New York :Longaman.

Clark, Leonard H. (1973). Teaching Social studies in Secondary Schools. USA: Macmillan Publishing Co.

DePorter, B., Reardon, M., \& Singer-Nourie, S. (2003). Quantum Teaching. Jakarta : Kaifa.

DeSimone, Christina. (2014). Problem Based Learning in Teacher Education Trajatories of Change. Vol. 4 No. 12

Esen, Ersoy. (2013). The Effects of Problem Bassed Learning Method in Higher Education on Creative Thinking: Education Faculty, Primary Mathematics Education Departement Izmir, Turkey.

Freire, Paulo. (2002). Politik Pendidikan, Kebudayaan, Kekuasaan, dan Pembebasan. Yogyakarta : Pustaka Pelajaran.

Graff, Erik De (2003) Characteristics of Problem Based Learning. Vol. 19, No 5657

Hasan, Said Hamid. (1995). Pendidikan Ilmu Sosial. Jakarta : Dirjen DIKTI, Depdikbud RI.
Hande. (2014). Acquisition on Knowledge, Generic Skills and Attitudes Through Problem Bassed Learning: Student Perspective in a hybrid Curriculum. Journal of Taibah University Medical Sciences.

Hidayati, Fitri. (2010). Pengembangan Perangkat Pembelajaran Berorientasi Model Pembelajaran Berdasarkan Masalah pada Mata Pelajaran IPA Pokok Bahasan Sumber Daya Alam. Surabaya: Tesis Megister Pendidikan UNESA.

Husama. (2011). Outdor Learning. Yogyakarta : Pinus Grup.

Ischak, dkk. (2004). Pendidikan IPS di SD. Jakarta : Pusat Penerbitan Universitas terbuka.

Isjoni. (2011). Pembelajaran Kooperatif Meningkatkan Kecerdasan Komunikasi antar Peserta Didik. Yogyakarta : Pustaka Pelajar.

Jingga. (2013) Pengembangan Silabus. Jakarta :Kencana.

Kelly, Orla C. (2007). Providing Solutions through Problem Based Learning for the Undergraduate $1^{\text {st }}$ Year Chemistry laboratory

Kemdikbud. (2012). Pedoman Penulisan Buku Ajar Peningkatan Kompetensi Pendidik Pendidikan Non Formal. Jakarta.

Kemp, E. J. Morrison, R. Gary. R. M. Steven. (1991). Designing Effective Intruction. New York : Macmillan College Publishing Company.

Kunandar. (2007). Guru Profesional, Implementasi Kurikulum Tingkatan Satuan Pendidikan dan Sukses dalam Sertifikasi. Jakarta: Rajawali Pers.

Lie, Alita. (2008). Cooperative Learning. Jakarta : PT Grasindo.

Martinis, Yamin. (2008). Paradigma Pendidikan Kontruktivisme. Jakarta : Gaung Persada (GP)

Nieven, N. (1997). Computer Support for Curriculum Developers: A Study On The Potential ofd Computer Support In The Domain of Formative Curriculum Evaluation. Doctoral dissertasi. Enscchede, the Netherlands : University of Twente.

Nusidik. (2009, Januari 2015). Diskripsi Rencana Pelaksanaan Pembelajaran. Dari http://www.wikipedia.org/

Sarwono. E. (2012). Pengaruh Penerapan Pembelajaran Outdor Learning Actifities pada Mata 
Pelajaran IPA di SD. Skripsi.

Salatiga:Universitas Kristen Satya Wacana.

Soetjipto, dkk. (1994). Profesi Guru. Jakarta: Direktorat Jendral Pendidikan.

Soemantri, Numan. (2001). Menggagas Pembaharuan Pendidikan IPS. Bandung : Rosda.

Subroto, Waspodo Tjipto. (2009). Bahan Pembelajaran Ilmu Pengetahuan Sosial. Surabaya: Unesa University Press.

Sugiyono. (2012). Metode Penelitian Kuantitatif, Kualitatif, dan $R \& D$. Bandung : Alfabeta.

Sulaeman. (2013). Pengembangan Perangkat Pembelajaran PKn Beracuan Model Pembelejaran Berdasarkan Masalah Untuk Meningkatkan Ketrampilan Sosial. Surabaya : Tesis Magister Pendidikan, Unesa.

Suprijono, Agus. (2010). Coopertive Learning. Surabaya: Pustaka Belajar.

Thiagarajan. (19740. Intructional Development for Training Teacher of Exseptional Children. Bloomington :Indiana University.

Wibowo, Yuni. (2010). Bentuk-bentuk Pembelajaran Outdoor. Jurnal Pendidkan. Yogyakarta : Universitas Negeri Yogyakarta.

Yang Luo. (2014). Investigation of Nursing Student Knowledge of and Attitudes About Problem Bassed Learning: International Journal of Nursing Sciences. 